\title{
A Nemzeti Véradó és Vérmentó Program szülészeti vonatkozásai
}

\author{
Oláh Zsolt dr. ${ }^{1}$. Deli Tamás dr. ${ }^{2}$ - Mühl Diána dr. ${ }^{3}$ \\ ${ }^{1}$ Debreceni Egyetem, Általános Orvostudományi Kar, Aneszteziológiai és Intenzív Terápiás Klinika, Debrecen \\ ${ }^{2}$ Debreceni Egyetem, Általános Orvostudományi Kar, Szülészeti és Nőgyógyászati Intézet, Debrecen \\ ${ }^{3}$ Pécsi Tudományegyetem, Általános Orvostudományi Kar, Aneszteziológiai és Intenzív Terápiás Intézet, Pécs
}

\begin{abstract}
A Nemzeti Véradó és Vérmentő Program célja a vérkészítmények észszerú és indokolt alkalmazásának támogatása és az irracionális transzfúziós gyakorlat megszüntetése, ezáltal a betegbiztonság növelése. Az általános elvek mellett a programnak vannak speciális szülészeti vonatkozásai is. A szülészeti, különösen a postpartum vérzések ugyanis világszerte az anyai halálozás vezető okai közé tartoznak, előfordulásuk pedig a fejlett országokban emelkedő tendenciát mutat. A szülésre való felkészülés fontos elemei a vérkép rendezése, a rutinszerű profilaktikus vagy terápiás vaspótlás és a szülészeti vérzés tekintetében nagy rizikóval rendelkező gravidák időben történő kiszúrése, gondozása. A peripartum vérzések legfóbb okai az abruptio placentae, placenta praevia, uterusatonia, szövetretenció a méh üregében, sérülés, a haemostasisrendszer zavarai és ezek kombinációi. A postpartum vérzés megelőzése érdekében a szülés során fontos a lepényi szak aktív vezetése, melynek alapvető eleme az uterotonikumok profilaktikus alkalmazása. A vérmentő technikák használata - megfelelő indikációval - császármetszés és postpartum vérzés során is megfontolandó. A szülészeti vérzések kezelése során a legfóbb prioritás a lumenes, sebészi vérzés szülész által történő ellátása. A maszszív vérzéshez társuló szekunder coagulopathia megszüntetése érdekében a faktorkoncentrátum-alapú, viszkoelasztikus teszttel monitorozott, egyénre szabott kezelési mód preferált, de ilyenkor a terhesség során érvényes - és a nem terhes állapottól eltérô - referencia- és célértékeket kell alkalmaznunk. A szülészeti vérzések részben a megelőzhető halálokok közé tartoznak. A Nemzeti Véradó és Vérmentő Program szülészeti alkalmazásával reményeink szerint tovább javíthatók a szülészeti vérzésekből származó morbiditási és mortalitásai adatok.
\end{abstract}

Orv Hetil. 2020; 161(37): 1588-1598.

Kulcsszavak: szülészeti vérzés, Patient Blood Management, masszív transzfúzió, anaemia, viszkoelasztikus haemostasisteszt

\section{Obstetrical aspects of the National Blood Donation and Blood Saving Program}

The aims of the National Blood Donation and Blood Saving Program are to support the rational and judicious utilization of blood products and abolish irrational transfusion policy to improve patient safety. In addition to the general principles, this program has got some special obstetrical aspects. Obstetrical, especially the postpartum haemorrhages belong to the leading causes of maternal mortality worldwide. In developed countries, a trend in increasing incidence can be observed. Preparing for delivery includes some important elements such as optimization of hemoglobin level, routinely applied prophylactic or therapeutic iron supplementation and early screening and comprehensive care of patients with high risk of obstetrical bleeding. The main causes of peripartum bleeding are abruptio placentae, placenta praevia, uterine atony, retained tissue in the uterus, trauma during delivery, and haemostatic disorders or their combinations. To prevent postpartum bleeding, it is important to use the active management of the third stage of labour including prophylactic utilization of uterotonics as an essential element. Utilization of blood salvage techniques with adequate indications may be considered in cases of cesarean section or postpartum haemorhage. In cases of obstetrical haemorrhage, management of surgical bleeding has the main priority by the obstetrician. Secondary coagulopathy associated with massive bleeding should be managed by viscoelastic test-guided, individualized and factor concentrate-based algorithm, however, pregnancy-specific reference and target ranges must be used that are different from the non-pregnancy values. Obstetrical bleedings belong to the potentially preventable causes of death. Hopefully, the implementation of the National Blood Donation and Blood Saving Program in the field of obstetrics can decrease the associated morbidity and mortality further.

Keywords: obstetrical bleeding, Patient Blood Management, massive transfusion, anemia, viscoelastic haemostatic test

Oláh Zs, Deli T, Mühl D. [Obstetrical aspects of the National Blood Donation and Blood Saving Program]. Orv Hetil. 2020; 161(37): 1588-1598.

(Beérkezett: 2020. május 22.; elfogadva: 2020. június 15.) 


\section{Rövidítések}

2,3-DPG = 2,3-difoszfoglicerát; A10, A20 = amplitúdó a CT végét követő 10,20 perccel (milliméter); $\mathrm{APTI}=$ aktivált parciális tromboplasztinidő; ATLS = (advanced trauma life support) a súlyos sérültek primer ellátásának protokollja ; $\mathrm{CFT}=$ (clot formation time) alvadékképződési idő; CRP = C-reaktív protein; $\mathrm{CT}=($ clotting time $)$ alvadási idő; $\mathrm{ESA}=$ erythropoesist stimuláló készítmény; EXTEM = az extrinszik alvadási mechanizmus vizsgálatára szolgáló viszkoelasztikus, betegágy melletti teszt; FFP = friss fagyasztott plazma; FIBTEM = (platelet inhibitor cytochalasin D) a fibrinogénszint vizsgálatára szolgáló viszkoelasztikus, betegágy melletti teszt; FII = a II-es számú alvadási faktor; $\mathrm{FV}=$ az V-ös számú alvadási faktor; FVII = a VII-es számú alvadási faktor; FVIII = a VIII-as számú alvadási faktor; FIX = a IX-es számú alvadási faktor; $\mathrm{FX}=\mathrm{a} \mathrm{X}$-es számú alvadási faktor; FXI = a XI-es számú alvadási faktor; FXII = a XII-es számú alvadási faktor; FXIII = a XIII-as számú alvadási faktor; $\mathrm{fl}=$ femtoliter $\left(10^{-9} \mathrm{l}\right)$; INR $=($ international normalized ratio) nemzetközi normalizált ráta; INTEM = az intrinszik alvadási mechanizmus vizsgálatára szolgáló viszkoelasztikus, betegágy melletti teszt; $i v$. = intravénás; $\mathrm{MCF}=$ (maximum clot firmness) maximális alvadékerôsség/amplitúdó (milliméter) $; \mathrm{MCV}=($ mean corpuscular volume $)$ átlagos vörösvérsejt-térfogat; NATA = Network for the Advancement of Patient Blood Management, Haemostasis and Thrombosis; $\mathrm{PAI}=$ plazminogénaktivátor-inhibitor; $\mathrm{PBM}=($ Patient Blood Management) hazai adaptációja a Nemzeti Véradó és Vérmentô Program; PI = protrombinido”; PPH = postpartum vérzés; TAFI $=$ (thrombin-activatable fibrinolysis inhibitor $)$ trombin által aktivált fibrinolysisinhibitor; THR = thrombocyta; TXA = tranexámsav; VE POC = (viscoelastic point-of-care) viszkoelasztikus, ágy melletti; VVS = vörösvérsejt; VWB = Von Willebrand-betegség; VWF = Von Willebrand-faktor; WOMAN trial $=$ World Maternal Antifibrinolytic trial

A Patient Blood Management (PBM) hazai adaptációja a Nemzeti Véradó és Vérmentő Program egy átfogó, komplex megközelítést alkalmazó, multidiszciplináris konszenzuson alapuló és egyénre szabott klinikai gyakorlat, melynek célja a vérkészítmények észszerű és indokolt alkalmazásának támogatása és az irracionális transzfúziós gyakorlat megszüntetése. A jelen közlemény a nemzetközi és a hazai irodalom áttekintése alapján ezen gyakorlat szülészeti vonatkozásait tárgyalja, melyet a szerzők - a hazánkban történő bevezetést elősegítendő a téma magyar nyelvü bemutatkozó, vitaindító anyagának szánnak.

A szülészeti vérzés, leginkább a postpartum vérzés (PPH) az anyai halálozás vezető okai közé tartozik világszerte, és az anyai összhalálozás 25-34\%-áért felelős [1, 2]. A PPH incidenciája 2-11\%-ra, súlyos formája 1-3\%ra tehető. Előfordulása - elsősorban az uterusatoniából származó típusa - emelkedő tendenciát mutat a fejlett országokban, amit - legalábbis részben - a szülésindukciók és a császármetszések gyakoriságának emelkedése, illetve az utóbbival összefüggésbe hozható és gyakoribbá váló beágyazódási rendellenességek magyaráznak [1-6].

A szülészeti vérzéseknek különös jelentôséget ad, hogy általában addig egészséges egyéneket érint, és köz- vetlen életveszélyt jelent számukra, miközben prevencióval és megfelelő kezeléssel halálozásuk csökkenthető, tehát részben a megelőzhető halálokok közé tartoznak. A szülészeti osztályokon végzett transzfúziók döntő részét - annak minden ismert veszélyével együtt - szintén a peripartum időszakban bekövetkező vérzések indokolják. A peripartum vérzések hosszú távú következményeivel, morbiditást növelő lehetséges hatásaival - hysterectomia és következményei, Sheehan-szindróma - szintén számolnunk kell. A fentiek egyértelmúvé teszik tehát a szülészeti vérzések megelőzésének és hatékony kezelésének, így a szülészeti PBM alkalmazásának kiemelkedő jelentőségét.

\section{A várandósságot kíséró élettani változások a haemostasis rendszerében}

A témát illetően elsősorban utalunk a közelmúltban megjelent kiváló, magyar nyelvű összefoglaló közleményre [7]. Terhesség során a keringő vértérfogat 3540\%-kal, a plazmatérfogat 40-50\%-kal, a vörösvérsejt (VVS)-térfogat 20-40\%-kal nő, így az alakos elemek relatív hígulása következik be [8]. Részben ennek következményeként benignus, nem súlyos gestatiós thrombocytopenia alakulhat ki a harmadik trimeszterre, illetve megváltozik az anaemia definíciója is terhességben (hemoglobin < $110 \mathrm{~g} / \mathrm{l}$ ), postpartum időszakban < $100 \mathrm{~g} / 1$ [9]. A nemzetközi adatokkal korrelálva, nagy esetszámú hazai felmérés is alátámasztja a nem várandós populációtól eltérő referenciaértékek alkalmazásának szükségességét terhességben, mely vizsgálat egyébként 114 g/l értéket határozott meg a normál-hemoglobinszint alsó határaként [10]. Nő a szívfrekvencia, a verőtérfogat, így a perctérfogat is, de csökken a perifériás vascularis rezisztencia és a vérnyomás. A Von Willebrand-faktor (VWF) és a fibrinogén szintje fokozatosan a duplájára emelkedik, így az utóbbi a terhesség harmadik trimeszterében normálisan már meghaladja a $3,5 \mathrm{~g} / \mathrm{l}$-es értéket [11, 12]. A FVII, a FVIII, a FX és a FXII szintje szignifikánsan nő, míg a FII, a FV és a FIX szintje alig változik. A FXIII szintje csökkenést mutat, a FXI változása kevésbé kiszámítható terhesség során [7, 13]. A természetes antikoagulánsok közül a protein $S$ szintje csökken, a protein $\mathrm{C}$ enyhén nő, az antitrombin jelentősen nem változik. Összességében a változások a prokoagulációs folyamatok irányába hatnak. A normális egyensúly a koagulációs rendszerben csak a szülés után 4-6 héttel áll helyre. A szöveti plazminogénaktivátor szintje csökken, a fibrinolysis folyamatát gátló rendszer alkotói (PAIl, PAI2, a2-antiplazmin, TAFI) túlsúlyba kerülnek, így a fibrinolyticus aktivitás visszaszorul. Közben a rendszerben jelentős tartalék épül fel a plazminogén mennyiségének emelkedése révén, hogy a szülés után a fibrinolysis/antifibrinolysis egység egyensúlya gyorsan, 24-48 órán belül helyreálljon, és ezzel segítse a méh üregéból az alvadék kiürülését és a szervezet thromboembolia elleni védekezését $[7,13]$. 
A terhesség során bekövetkezó élettani - fóként prothromboticus irányú - változások tehát elsősorban a peripartum, életet veszélyeztető vérzések elkerülését szolgálják, hiszen a placenta vérátáramlása a terminus idején eléri, illetve meg is haladhatja a perctérfogat 10\%-át (650-700 ml/perc) [7]. A szülés után a haemostasis rendszerében majd csak fokozatosan, hetek alatt áll viszsza a terhesség előtti egyensúlyi állapot.

\section{A szülészeti vérzések típusai, definíciójuk és eredetük}

A szülészeti vérzéseket azok szüléshez viszonyított, időbeli jelentkezése alapján ante- vagy postpartum csoportokba soroljuk.

$\mathrm{Az}$ antepartum vérzés a 24. gestatiós hét és a magzat világrajövetele között alakul ki. Egyesek elkülönítik az intrapartum vérzés fogalmát, mely a szülés megindulása után, de a magzat megszületése előtt jön létre. Az antepartum vérzések okai között kiemelkedő jelentőséggel bírnak a placentaris eredetú vérzések (placenta praevia, vasa praevia, abruptio placentae) és a ritka, de masszív vérzéshez vezető uterusruptura [14].

A PPH-nak többféle definíciója létezik, de közös bennük, hogy a vérvesztés mértékének becslésén és a hemodinamikai következmények értékelésén alapulnak.

A klasszikus definíció szerint primer PPH-ról beszélünk, ha hüvelyi szülés esetén 500 ml-t, császármetszés esetén 1000 ml-t meghaladó mennyiségü vérvesztés vagy hemodinamikai következménnyel járó (fokozódó tachycardia és hypotensio), hypovolaemiához vezető vérzés jelentkezik a szülést követő 24 órán belül [ 15 , 16]. A PPH definiálásakor több orvostudományi társaság a szülés módjától függetlenül, 500 ml-ben határozza meg a vérvesztés mennyiségét a szülést követő 24 órán belül [2]. A vérzés mennyisége alapján a $\mathrm{PPH}$ súlyos (1000-2500 ml vérvesztés) és masszív, életet veszélyeztető (>2500 ml vérvesztés vagy hypovolaemiás sokk kialakulása esetén) kategóriáit különítjük el. A primer PPH a leggyakoribb szülészeti vérzéstípus. A leggyakrabban uterusatonia (70-80\%), ritkábban szövetretenció (méhlepény, burok, vérömleny), sérülés (uterusruptura, -perforatio, -inversio, a méhszáj, hüvely, gát sérülése), a haemostasisrendszer zavarai (örökletes vagy szerzett, vérzékenységet okozó betegségek, eltérések; antikoaguláns gyógyszerelés) és ezek kombinációi vezetnek súlyos peripartum vérzésekhez.

Szekunder PPH-ról a szülés utáni 24 órán túl, de a 12. hét előtt bekövetkező, a genitalis traktusból származó, $\geq 500 \mathrm{ml}$ mennyiségú vérzés esetén beszélünk.

\section{A Nemzeti Véradó és Vérmentő Program alkalmazása a várandósság során}

A perioperatív Nemzeti Véradó és Vérmentő Program gyakorlati megvalósítása három pilléren nyugszik: 1. a vérkép rendezése, lehetőleg transzfúzió nélkül; restriktív transzfúziós gyakorlat alkalmazása; 2 . a vérvesztés minimalizálása; 3. az anaemiával szembeni tolerancia fokozása [17]. A PBM általános elemeit A perioperatív vérgazdálkodási program alapelvei címú kéziratban már kifejtettük, így az abban leírtakat nem ismételjük meg. Kidolgozásra kerültek azonban a különböző szakterületeket érintő PBM-programok is, melyek speciális szülészeti vonatkozásait az alábbiakban részletezzük [18-20].

\section{$A$ vérkép rendezése}

Minden várandós nőnél szükséges a vérkép ellenőrzése és követése már az első trimesztertől kezdve. Anaemia fennállása esetén a kóreredet tisztázandó és annak megfelelően kezelendő. Fejlett országokban a terhesség során észlelt anaemia a leggyakrabban vashiányra vezethető vissza, mely a megnövekedett igénynek és a vasbevitel relatív vagy abszolút elégtelenségének tulajdonítható. A terhesség során fennálló vashiányos anaemia növeli mind az anyai, mind a perinatalis morbiditás és mortalitás rizikóját [21].

Terhességben, anaemia hiányában is napi $30 \mathrm{mg}$ elemi vas bevitele javasolt per os a terhességi anaemia megelözése érdekében, a vastúlterheléssel járó ritka esetek kivételével [22]. A várandós nők számára kifejlesztett multivitamin-készítmények általában megfelelnek ennek a feltételnek. Amennyiben mellékhatások miatt a napi vasbevitel nem oldható meg, alternatívát jelenthet a másnaponként 30-60 mg (60 mg elemi vasat tartalmaz $300 \mathrm{mg}$ vas-szulfát, $180 \mathrm{mg}$ vas-fumarát vagy $500 \mathrm{mg}$ vas-glükonát) vagy legalább heti $1 \times 120 \mathrm{mg}$ elemi vas szedése [23]. A vaskészítmények másnaponként történő per os szedése maximalizálja a vas felszívódási arányát, mérsékli a mellékhatások számát, miközben hasonlóan hatékony a napi vasbevitellel összehasonlítva, így ma már egyre szélesebb körben alkalmazzuk ezt a gyakorlatot [24].

Minden anaemiás várandósnál, illetve microcytás vérképzés esetén $(\mathrm{MCV}<80 \mathrm{fl})$ fontos a ferritin, a transzferrinszaturáció, indokolt esetben a CRP és a vesefunkció ellenőrzése.

Vashiányos anaemia fennállásakor naponta, másnaponként 40-120 mg elemi vas bevitele javasolt a vérkép és a vasraktárak telítettségének rendezéséig, majd át lehet térni a fentebb említett profilaktikus adagolási módra $[21,22]$. Amennyiben az anaemia gyors rendezése szükséges, vagy a per os vaskészítményt a várandós nő nem tolerálja, esetleg hatástalannak bizonyul, a 2. és a 3. trimeszterben, illetve a postpartum időszakban intravénás (iv.) vaspótlás javasolható [2, 21-24].

\section{Transzfúziós gyakorlat a várandósság alatt}

Az allogén vérkészítmények alkalmazása megfelelő indikáció esetén életmentő, indokolatlan alkalmazásuk azonban számos rövid és hosszú távú, akár életet is veszélyeztető következménnyel járhat, ezért kerülendő [25-32]. 
Terhességben nem állnak rendelkezésre randomizált, nagy betegszámot magukban foglaló tanulmányok a transzfúzió hatásait illetően, így elsősorban más betegcsoportok adatainak extrapolálásával vonhatunk le következtetéseket.

Terhesség alatt, megfelelő gondozás mellett - az akut vérzés és néhány speciális entitás (sarlósejtes anaemia, thalassaemia stb.) kivételével - ritkán találkozunk transzfúziót igénylő anaemiával. Általánosságban kijelenthető, hogy <70 g/1 hemoglobinértéknél szinte mindig, >90$100 \mathrm{~g} / 1$ érték esetén pedig aligha indokolt transzfúzió. Köztes hemoglobinértékeknél, nem aktív vérzéshez társuló anaemia esetén a transzfúzió szükségességének elbírálásakor a következő szempontokat kell mérlegelni: 1) A várandós szempontjából transzfúzió akkor indokolt, ha az anaemia szignifikáns tüneteket, panaszokat okoz. 2) Meghatározó a terhességi kor. Ha nincs idő a vaspótlás, illetve az egyéb kezelések hatásának kivárására, transzfúzió adása még a szülés előtt javasolt. Ha a szülés alatti normálmértéket meg nem haladó vérvesztéssel kalkulálva is csaknem bizonyos, hogy transzfúziót indokoló anaemia fog kialakulni, nincs ok a transzfúziónak a postpartum időszakra halasztására, hiszen egy vártnál nagyobb vérzés hamar életveszélyes állapotot okozhat, illetve a vajúdás alatti csökkent lepényi perfúzió a magzat egészségét veszélyeztetheti. A szülészeti vérzés tekintetében nagy rizikóval rendelkező betegek esetében ez a szempont hatványozottan érvényesül. 3) A magzat és a placenta állapota is döntő. Ha anaemia mellett elégtelen lepényi funkcióra utaló morfológiai UH-jeleket (méhen belüli növekedési sorvadás, oligohydramnion stb.) észlelünk, és/vagy Doppler-vizsgálattal a krónikus magzati hypoxia kiváltotta keringéscentralizáció ismert ultrahangjeleit (emelkedett rezisztencia és pulzatilitási indexek az arteria umbilicalisban, majd end-diastolés stop vagy reverz áramlás megjelenése, illetve csökkent rezisztencia és pulzatilitási index a magzati arteria cerebri mediában) látjuk, az anyai anaemia mihamarabb korrigálandó.

A transzfúziós cél meghatározása tehát minden esetben egyénre szabottan történjen, figyelembe véve a társbetegségeket, az aktuális klinikai helyzetet, a szülés várható időpontját, a szülészeti vérzés rizikófaktorainak jelenlétét és a magzat, valamint a placenta állapotát az anaemia mértéke mellett; döntésünket a helyi viszonyokat is magukban foglaló protokollok segíthetik [33]. Indokolt esetben a transzfúzió alkalmazásával - a hemoglobin értékétől függetlenül - nem szabad késlekedni.

\section{A vérzékeny várandósok kiszürése}

A veleszületett és/vagy szerzett vérzékenységben szenvedő terhesek fokozott rizikóval rendelkeznek a szülészeti vérzések tekintetében, ezért nagyon fontos ezeket a betegeket időben kiszürni és szükség esetén kezelni vagy profilaxisban részesíteni $[2,20]$. Ideális esetben a vérzékenységhez vezető diagnózis már a fogamzás előtt ismert, enyhe vérzékenység azonban akár ismeretlen is maradhat. A várandósgondozás része kell, hogy legyen a vérzékenységirányú szürővizsgálat, melyben segítséget nyújt akár az egyszerüsített, akár a részletes vérzékenységi kérdőív (lásd: 1561-1562. és 1563. oldal, 1. és 2. melléklet) a laboratóriumi tesztek mellett. A vérzékeny betegek gondozását szoros együttmúködésben végezze szülész és hematológus, valamint invazív beavatkozások során és a peripartum időszakban fontos szerep jut az aneszteziológusnak, illetve intenzív terápiás szakembernek. Elöre felállított és egyénre szabott gondozási és kezelési terv szükséges a vérzékeny betegek ellátása során, különösen a peripartum időszakkal kapcsolatban. A leggyakoribb, definitív, veleszületett vérzékenységgel járó kórképek a terhesség során a Von Willebrand-betegség (VWB), valamint a haemophilia A- és B-hordozó állapot [20]. A bizonyos gyógyszerek és/vagy társbetegségek által okozott szerzett vérzékenységekkel azonban még frekventáltabban találkozhatunk. A vérzékenység általános diagnózisát - legyen az veleszületett vagy szerzett - elsősorban a klinikai jelek alapján állítjuk fel, így előfordulhat, hogy - ismerve a vérzékenységgel járó kórképek széles repertoárját és a laboratóriumi kivizsgálás nehézségeit (például számos ritka, de összességében mégis gyakorinak mondható, thrombocytopathiával járó kórkép) - definitív diagnózis nem születik ugyan, de a várandóst mégis vérzékenynek tartjuk, és ennek megfelelően gondozzuk, kezeljük. Ilyen esetben is el kell jutnunk legalább a csoportdiagnózis szintjéig (thrombocytopathia/penia, a fibrinolysis zavara, coagulopathia stb.), mely a további kezelési terv meghatározásában segíthet. A konvencionális haemostasistesztek (protrombinidő, aktivált parciális tromboplasztinidő, trombinidő és fibrinogén) egyes vérzékeny betegek kiszưrésében szintén fontos szerepet játszhatnak. A fibrinogénszint mérése segít a $\mathrm{PPH}$ várható súlyossági fokának előrejelzésében: a szülés előtt igazolt alacsony fibrinogénszint mellett nagyobb valószínúséggel alakulhat ki PPH, a PPH kialakulása pedig rosszabb prognózist, súlyosabb vérzést valószínűsít [12]. A terhesség során az alvadási faktorok többségének szintje emelkedik, így a vérzékenység súlyossági foka csökkenhet, átmenetileg akár meg is szünhet, míg más faktorok szintje (például FIX - haemophilia B-hordozó állapot, FXIII) nem változik, esetleg tovább csökken, akár még tovább súlyosbítva a kórkép klinikai megjelenését [13]. A közlemény terjedelme határt szab a vérzékenységgel járó kórképek részletes ismertetésének, de fontos tudni, hogy jelentős individuális különbségek lehetnek a faktorszintek alakulásában, ezért az adott paramétereket (például VWF-szint és aktivitás VWB-ben) a terhesség során követni kell, és szükség esetén profilaktikus vagy kezelési céllal faktorpótlás válhat szüikségessé $[2,13]$. A faktorpótlás vezetését a haemostasisban jártas hematológusra kell bízni, vele szoros együttmúködésben kell végezni, különösen nagy figyelmet fordítva a peripartum időszakra a szülészeti vérzések elkerülése érdekében. 
1. táblázat | A szülészeti vérzések fontosabb rizikófaktorai

\begin{tabular}{|c|c|}
\hline Szülés előtt ismert állapotok & $\begin{array}{l}\text { Szülés alatt/után ismertté váló } \\
\text { állapotok }\end{array}$ \\
\hline Placenta praevia & Abruptio placentae \\
\hline $\begin{array}{l}\text { Placenta accreta/increta/ } \\
\text { percreta }\end{array}$ & $\begin{array}{l}\text { Sürgősséggel végzett császármet- } \\
\text { szés }\end{array}$ \\
\hline PPH az anamnézisben & Placentaretenció \\
\hline Anaemia $(\mathrm{Hb}<90 \mathrm{~g} / \mathrm{l})$ & Hüvelyi szülésbefejező műtét \\
\hline $\begin{array}{l}\text { Örökletes vagy szerzett } \\
\text { vérzékenység }\end{array}$ & Elhúzódó vajúdás \\
\hline $\begin{array}{l}\text { Multiparitás }(>3) \text {, anamnézisben } \\
\text { uteruson végzett mútét }\end{array}$ & Viharos szülés \\
\hline $\begin{array}{l}\text { Praeeclampsia, terhességi } \\
\text { hypertensiv kórképek }\end{array}$ & Fájáserősítés oxitocinnal \\
\hline Ikerterhesség & Szülés során bekövetkező sérülés \\
\hline $\begin{array}{l}\text { Atoniát okozó gyógyszerek } \\
\text { szedése }\end{array}$ & Chorioamnionitis \\
\hline Az anya életkora $\geq 35$ év & Elhúzódó lepényi szak \\
\hline Leiomyoma uteri & Uterusruptura, uterusinversio \\
\hline Fibrinogén<3,5 g/1 & Általános narkózis szükségessége \\
\hline Mors in utero & $\mathrm{DIC}$ \\
\hline Nagy magzat & \\
\hline
\end{tabular}

$\mathrm{DIC}=$ disszeminált intravascularis koaguláció; $\mathrm{Hb}=$ hemoglobin; $\mathrm{PPH}$ = postpartum vérzés

\section{A szïlészeti vérzések kockázati tényezöinek azonositása és kezelése}

A szülészeti vérzések legfontosabb rizikófaktorait az 1 . táblázatban foglaltuk össze. Ezek egy része már a szülés előtt is fennáll, így korán azonosítható, mások csak a szülés során jelentkeznek, illetve derülnek ki. A rizikófaktorok között vannak olyanok, melyeket érdemben tudunk befolyásolni (például az anaemia kezelése, a vérzékeny várandósok kiszűrése és megfelelő előkészítése, faktorpótlás stb. a terhesség alatt és a szülés előtt), és így tudjuk mérsékelni a vérzés bekövetkeztének valószínúségét, míg sok esetben csak a rizikófaktor jelenlétét tudjuk konstatálni. Az utóbbi azonban ugyanolyan fontos, hiszen a vérzés veszélyével ilyenkor már fokozottan számolunk, így egyénre szabott módon tudunk felkészülni rá.

A szülészeti vérzés fokozott rizikója esetén fontos a várandós megfelelő tájékoztatása és előzetes beleegyezése egy esetleges - az összes egyéb lehetöség sikertelensége után - életmentó céllal végzett hysterectomiába, megfelelő progresszivitási szintû́ intézményben történő ellátás, nagy tapasztalattal bíró szülész és aneszteziológus bevonása, masszív vérzés ellátásához szükséges további személyi és tárgyi feltételek biztosítása (megfelelő mennyiségben elérhető faktorkoncentrátumok, vérkészítmények stb.).

\section{A lepényi szak aktín kezelése}

A lepényi szak aktív kezelésével csökkenthető a szülés utáni vérzés mennyisége, a $\mathrm{PPH}$ kialakulásának veszélye [2]. Az aktív kezelés fó elemei az uterotonikumok, első vonalban az oxitocin rutinszerú alkalmazása és az ellenőrzött köldökzsinórhúzás az uterus kontrakciója során. A korábban alkalmazott korai köldökzsinór-lefogás nem csökkenti a PPH kialakulásának valószínúségét. Ma elsősorban az újszülött számára előnyös késleltetett vagy fiziológiás lefogást javasolják, mely az anya számára nem jár hátrányos következményekkel [2].

Hüvelyi szülés és császármetszés esetén is profilaktikus oxitocin javasolt iv. 5-10 NE dózisban lassan (30-60 s) vagy bolus formájában, illetve ezt követően szükség esetén fenntartó adagolásra váltunk, folyamatos infúzióban adva. Szív-ér rendszeri betegségben szenvedő terheseknél az oxitocin beadása lassan (legalább 5 perc) történjen a nemkívánatos hemodinamikai következmények elkerülése érdekében. Császármetszés esetén fenntartó oxitocinadás rutinszerúen javasolt folyamatos infúzió, esetleg iv. bolus formájában. A fenntartó adagolás két óra után leállítható, ha az uterus tónusa kielégítô, és nincsenek fokozott vérzésre utaló jelek [2]. A szülésindukció, illetve a szülés első és második fázisában tartósan, nagy adagban alkalmazott oxitocin növeli a PPH veszélyét [34]. Tranexámsav (TXA) rutinszerú alkalmazása nem javasolt, de elsősorban császármetszéseknél megfontolandó magas PPH-rizikó vagy antepartum vérzés esetén $[2,35]$. A magzat világrajövetele után nagy PPH-rizikó esetén prosztaglandinszármazék (szulproszton) profilaktikus adagolása szintén megfontolandó.

\section{Vérmentés, 'cell saver' használata}

A 'cell saver' szülészeti indikációval történő alkalmazása számos nemzetközi orvostársaság ajánlásában szerepel [36]. Válogatott esetekben alkalmazva biztonságos, hatékony és költségkímélő. Használata megfontolandó azoknál a terheseknél, akiknél masszív szülészeti vérzés alakul ki, vagy nagy a PPH becsült rizikója, tehát a császármetszés során a várható vérvesztés meghaladja az 1000 ml-t, illetve ebből adódóan vagy egyéb okból nagy a VVS-transzfúzió esélye [36]. Leggyakoribb szülészeti indikációi a következők: placenta accreta/increta/percreta, placenta praevia, PPH miatt végzett laparotomia, anamnézisben szereplő PPH, sürgősségi császármetszés, anamnézisben $\geq 3$ császármetszés, ikerterhességek, PPH fennállása. Császármetszés során nem szülészeti indikáció alapján meg kell fontolni a 'cell saver' használatát súlyos preoperatív anaemia, veleszületett vagy szerzett vérzékenység, thrombocytopenia, vérválasztási nehézségek esetén, illetve amennyiben a beteg az allogén transzfúzió lehetőségét eleve elutasítja. A 'cell saver' használatának legismertebb kontraindikációi közé tartozik a kontamináció (biológiai: faecalis, bakteriális; farmakológiai: például lokálisan alkalmazott hemosztriptikumok vagy 
olyan szerek, amelyek $i v$. nem adhatók), heparin indukálta thrombocytopenia, malignus alapbetegség és sarlósejtes anaemia. A 'cell saver' használatával elkerülhetjük vagy csökkenthetjük az allogén vérkészítmények menynyiségének transzfúzióját annak minden potenciális veszélyével. Az allogén VVS-koncentrátummal összehasonlítva, a beavatkozás során gyújtött és szeparált, feldolgozott autológ VVS-koncentrátum minden paraméter tekintetében (hőmérséklet, 2,3-DPG-szint, káliumszint stb.) közelebb áll az élettani értékekhez, és citrátot sem tartalmaz [36]. Rh-negatív vércsoporttal rendelkező anya Rh-pozitív magzata esetén az alloimmunizáció kivédése érdekében anti-D-immunglobulin alkalmazása rutinszerú. 'Cell saver' használata során az anyai keringésbe kerülő magzati VVS-ek száma megemelkedhet, ami a beadandó anti-D-immunglobulin dózisát szintén emelheti (a számításkor az úgynevezett Kleihauer-Betke-teszt segíthet, mely a magzati VVS-ek arányát képes meghatározni az anyától vett vérmintában). Leukocytafilter jelentősen csökkentheti a baktériumok, malignus sejtek és a magzatvízben levő egyéb sejtek beadott mennyiségét, használata azonban hypotensiót okozhat a filterrel megkötött fehérvérsejtek által termelt citokinek hatása miatt [36].

Egyértelmúen igazolt magzatvíz-emboliát 'cell saver' használatával kapcsolatban még nem közöltek, a visszaadott VVS-koncentrátumban ugyanolyan mennyiségben tudtak fetalis laphámsejteket kimutatni, mint az anyai vérben a placenta leválásakor [37]. Ennek ellenére - habár nemzetközi ajánlásban már szerepel - betegbiztonsági okokból és a magzatvíz-emboliával kapcsolatos félelmek miatt - nagy betegszámú vizsgálat hiányában - szülészeti alkalmazása még nem terjedt el széles körben. Megfelelő indikáció esetén és ellenjavallat hiányában azonban alkalmazása megfontolandó.

\section{A szülészeti vérzések ellátása}

$\mathrm{Az}$ antepartum vérzéseknél elsődlegesen a terhesség befejezésének szükségességéről kell szülészeti döntést hozni, melyet a terhességi kor, az anyai és a magzati állapot, illetve a vérzés mértéke, ismétlődése és időtartama határoz meg. Ezzel egy időben fel kell készülni a mütét alatt és postpartum jelentkező masszív vérzés lehetőségére és ellátására. A PPH-val kapcsolatos halálozás 90\%-a a szülés után 4 órán belül következik be [38]. A PPH, de alapvetően bármely szülészeti vérzés kialakulásának - az arra utaló direkt vagy indirekt jelek - lehető legkorábbi észlelése, a szülés utáni szoros obszerváció és a kezelés azonnali elkezdése tehát kulcsfontosságú. Ezen folyamat fontos része a vérvesztés mértékének rutinszerü és standardizált felmérése minden egyes szülésnél, ami jelentős klinikai tapasztalattal ruházza fel a személyzetet a normál és a patológiás mennyiségű vérvesztés elkülönítésében. A vérvesztés felmérését a vizuális becslésen túl az erre a célra kifejlesztett, szüléseknél használatos, mennyiségi beosztással rendelkező, az elfolyt vért felfogó mérőedé- nyek/zacskók és a használt egészségügyi törlők, tamponok súlyának mérése segítheti. Ezek során nemcsak a vér, hanem a magzatvíz, öblítőfolyadék stb. is lemérésre kerül, melyek becsült mennyiségét szintén ismernünk kell a korrekt számításhoz [2]. A terhes szervfunkcióinak monitorozása során nyert klinikai adatok szintén segítik az elvesztett vér mennyiségi becslését. Az ATLS klasszifikációja alapján négy csoport különíthető el: Az 1. csoportban a vérvolumen < 15\%-a vész el, a szívfrekvencia minimálisan emelkedhet, de érdemi hemodinamikai megingás nem tapasztalható. A 2 csoportban a vérvolumen 15-30\%-a vész el. Tachycardia (100120/perc), tachypnoe (20-24/perc), csökkent pulzusnyomás, húvös, verejtékes bőr és kóros kapillárisújratelődési idő, de közel megtartott systolés vérnyomásérték jellemzi. Ez a kompenzált sokk stádiumának felel meg, az ok azonnal keresendő. A 3. súlyossági csoportban 30-40\%-os vérvolumenvesztés áll fenn. A vérnyomás csökken, a mentális status megváltozik, a szívfrekvencia és a légzésszám tovább emelkedik, az óradiuresis lecsökken. A 4. csoportban a vérvesztés meghaladja a teljes volumen $40 \%$-át, a beteg a sokk egyértelmú jeleit mutatja, állapota kritikus [39].

A PPH ellátását az 1. ábrán foglaltuk össze. A PPHért felelős vérzések kezelése során elsődleges a sebészi vérzéscsillapítás, azaz a lumenes és traumás vérzés szülész által történő ellátása, a méh üregében visszamaradt szövetek maradéktalan eltávolítása és - különösen atonia esetén - uterotonikumok megfelelő időben és mennyiségben történő alkalmazása. Időt nyerhetünk bimanuális uteruskompresszió, intrauterin Dührssen-féle vagy ballontamponád és külső aortakompresszió alkalmazásával mind hüvelyi szülés, mind császármetszés után, amenynyiben a hasüreget már zárták $[2,40]$. Nyitott has esetén az aorta direkt kompressziója, az uterusba kompressziós öltések behelyezése, illetve az arteria uterina vagy iliaca interna lekötésével devascularisatio jön szóba [2, 40]. Hemodinamikai stabilitás esetén akár szelektív arteriaembolisatio is alternatíva lehet a PPH kezelésében. Végső esetben, illetve közvetlen életveszély esetén pedig azonnali hysterectomia végzendő. Az oxitocin lepényi szakban, megfelelő időben történő rutinszerű alkalmazása csökkenti a PPH rizikóját. Uterusatonia esetén az oxitocin adagja emelhető, illetve egyéb uterotonikumok (oxitocinanalógok, például karbetocin; prosztaglandinszármazékok, például szulproszton, karboproszt-trometamin) alkalmazása is szóba jön elérhetőségüktől függően [2].

A sebészi vérzéscsillapítással párhuzamosan, a hemodinamikai állapottól függő volumenresuscitatio indokolt; elsősorban VVS-transzfúzióval, krisztalloid \pm kolloid infúziókkal, szükség szerint thrombocytatranszfúzióval, illetve faktorkoncentrátumok egyidejű alkalmazásával a társuló coagulopathia mihamarabbi megszüntetésére törekszünk (lásd később) [41, 42]. A transzfúziós igény megítélésekor fontos a centrális vénás szaturáció (<70\%), a laktátszint- (>2 mmol/l) és a nem invazív/invazív he- 


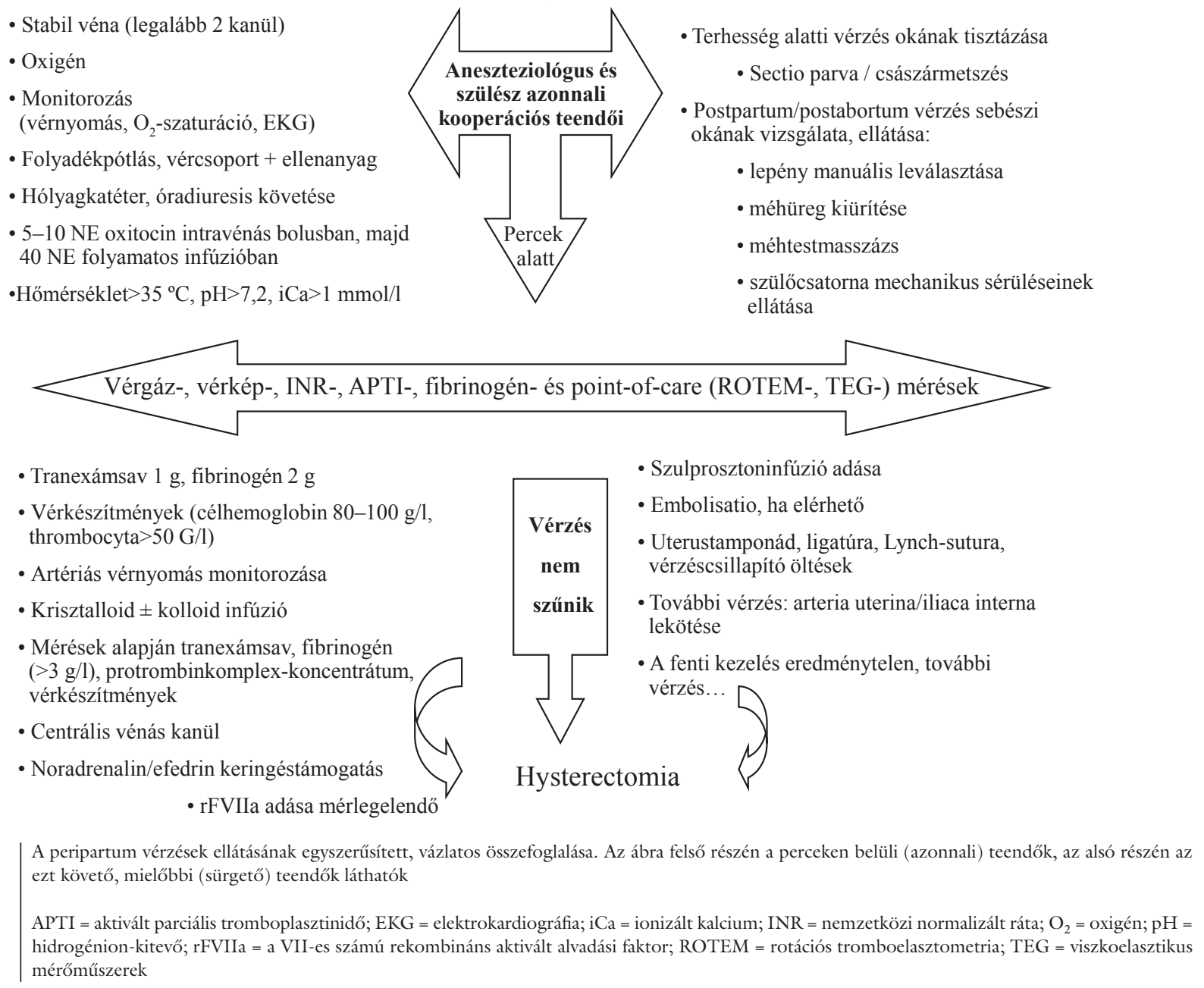

modinamikai monitorozás is. Szülés előtt VVS-koncentrátum tartalékolása javasolt a szülészeti vérzés tekintetében nagy rizikóval bíró várandósok, a veleszületett vagy szerzett vérzékenységben szenvedő terhesek esetében és azoknál, akik olyan ritka alloantitesttel rendelkeznek, amely a kompatibilis VVS-koncentrátum biztosítását, hozzáférhetőségét megnehezíti [19]. Thrombocytatranszfúzió akut vérzés során $75 \mathrm{G} / 1$ alatti vérlemezkeszámnál indokolt, a cél az >50 G/1 szint megtartása [2].

Fontos a homeostasis (elsősorban a sav-bázis háztartás egyensúlya, normothermia, normális ionizáltkalciumszint) helyreállítása és fenntartása a haemostasisrendszer hatékony múködéséhez. Szükség esetén a haemostasis múködésére negatívan ható gyógyszerek hatásának felfüggesztése javasolt [41, 42]. A szülés és a vérzés következtében kialakuló faktorvesztés, consumptio, a kezeléshez társuló dilutio és a kiterjedt szövetkárosodás, sokkos keringés kapcsán kifejlődő hyperfibrinolysis és traumás coagulopathia révén szekunder coagulopathia kialakulásával számolhatunk, mely a lumenes vérzéssel szemben diffúz, folyamatosan szivárgó vérzést okoz, és jelentősen hozzájárul a $\mathrm{PPH}$ progressziójához, ezen keresztül pedig a morbiditási és mortalitási adatok növekedéséhez.
A szekunder coagulopathia kezelése elsősorban az aneszteziológus feladata, mely természetesen csak akkor lehet sikeres, ha a szülészeti vérzés ellátásában az elsődleges, kulcsszerepet játszó szülész a lumenes, sebészi vérzést uralni tudja.

A peripartum masszív vérzésekhez társuló szekunder coagulopathia modern kezelése során a stabil faktorkoncentrátum-alapú, célvezérelt és viszkoelasztikus pointof-care (VE POC-) teszttel monitorozott terápia $(2 / a$ ábra) preferált az allogén vérkészítményeket fix arányban alkalmazó (FFP : VVS : THR) és/vagy hagyományos haemostasis alvadási tesztekkel (PI, APTI) történő monitorozáson alapuló (2/b ábra) szemlélettel szemben [43]. Ez a fajta megközelítés eleve igyekszik a masszív transzfúziót elkerülni, illetve megelőzni. A helyi viszonyokhoz igazított, de a nemzetközileg elfogadott alapelvek mentén megalkotott és rendszeresen revideált maszszívvérzés-ellátási protokoll alkalmazása javasolt minden intézményben.

A terhesség során a haemostasis rendszerében bekövetkező, elsősorban prothromboticus irányú élettani változások a VE POC-tesztek referenciaértékeit is megváltoztatják $[44,45]$ : 


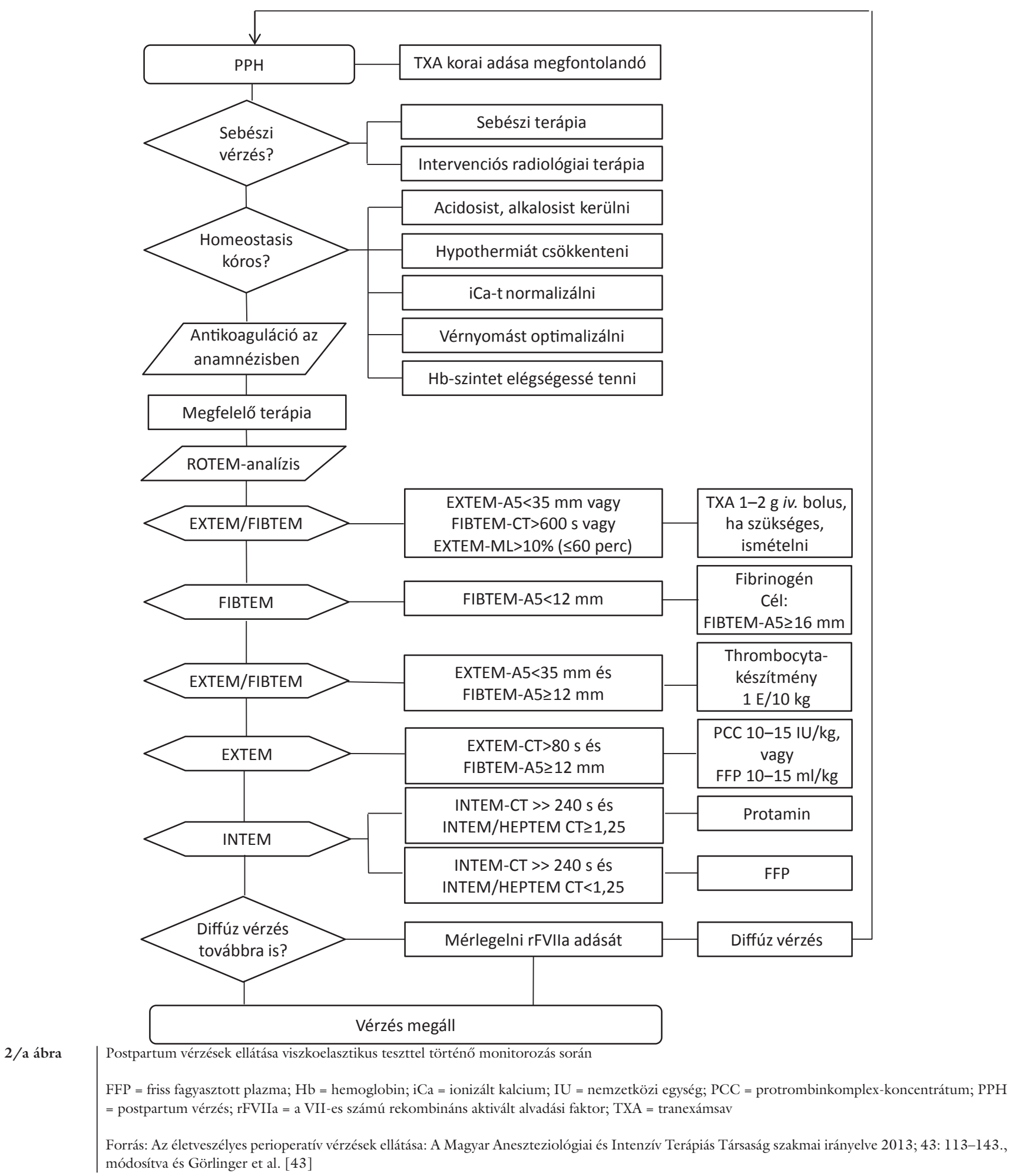

- Az EXTEM- és az INTEM-CT és -CFT terhességben rövidebb.

- Az INTEM- és FIBTEM-A10, -A20 értékei magasabbak, elsősorban a referenciatartomány felső határa.

- Az alfa-szög és az MCF-értékek szintén magasabbak. A peripartum vérzések ellátásakor ennek megfelelően más referencia- és célértékeket alkalmazunk. Vizsgálatok igazolták, hogy a korai időszakban mért amplitúdóérté- kek (A5, Al0, Al5) nagyon jó korrelációt mutatnak a vérrög erősségét, stabilitását tükröző MCF-értékkel, ami lehetővé teszi a még korábbi, adekvát intervenció alkalmazását [43].

Haemostasisintervenció csak indokolt esetben, vérzés esetén, kimutatott eltérés korrekciója céljából történjen, elsősorban a VE POC-tesztek eredményei alapján [41, $43,46]$. Faktorkoncentrátumok és allogén vérkészítmé- 


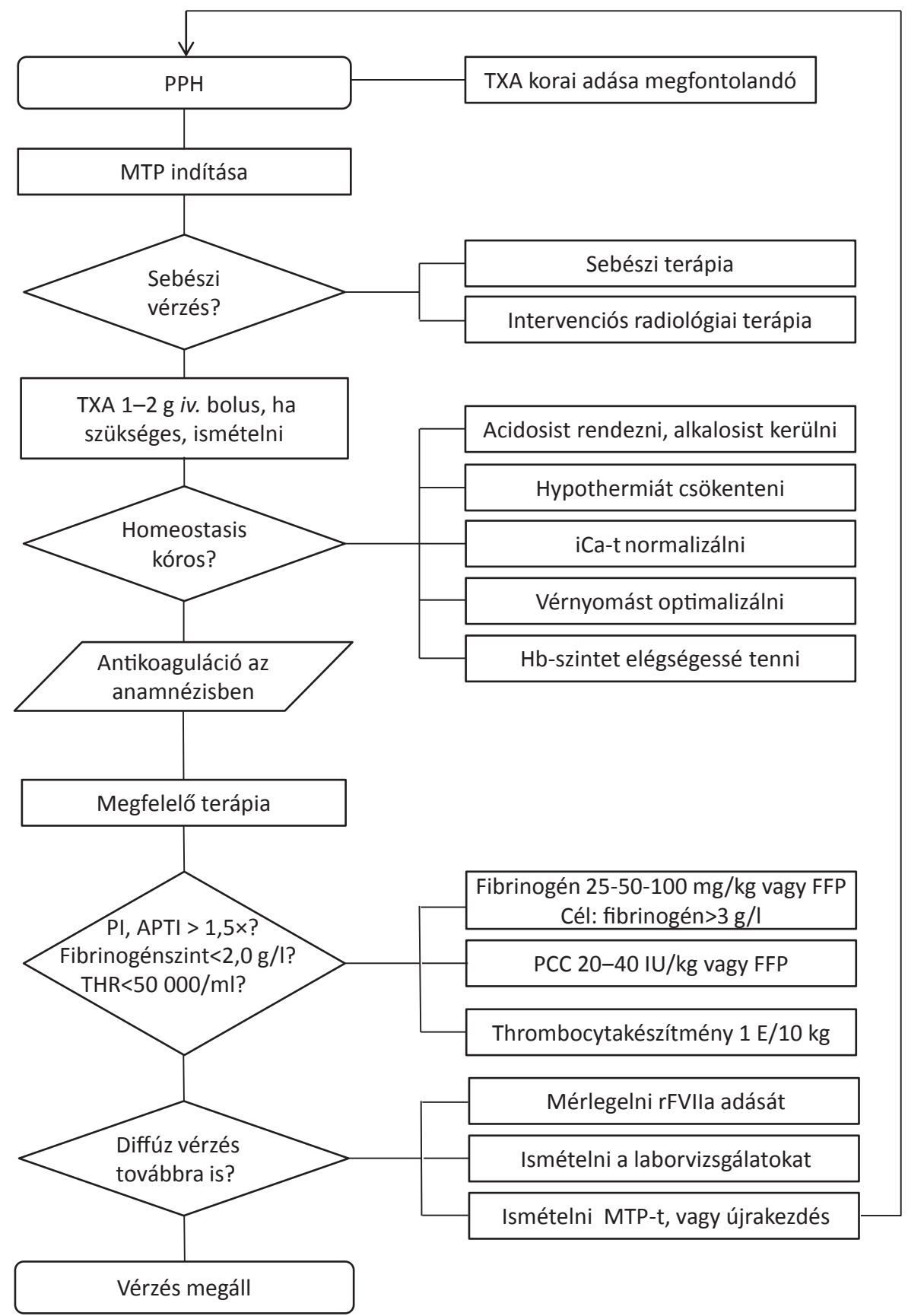

2/b ábra $\quad$ Postpartum vérzések ellátása viszkoelasztikus teszt hiányában

APTI = aktivált parciális tromboplasztinidő; FFP = friss fagyasztott plazma; Hb = hemoglobin; iCa = ionizált kalcium; IU = nemzetközi egység; MTP = masszív transzfúziós protokoll; $\mathrm{PCC}=$ protrombinkomplex-koncentrátum; $\mathrm{PI}=$ protrombinidő; $\mathrm{PPH}=$ postpartum vérzés; rFVIIa $=\mathrm{a}$ VII-es számú rekombináns aktivált alvadási faktor; $\mathrm{THR}=$ thrombocyta; $\mathrm{TXA}=$ tranexámsav

Forrás: Az életveszélyes perioperatív vérzések ellátása: A Magyar Aneszteziológiai és Intenzív Terápiás Társaság szakmai irányelve 2013; 43: 113-143., módosítva

nyek profilaktikus alkalmazása - az ismert vérzékenységben szenvedő betegek kivételével - nem indokolt. A szülés előtt végzett VE POC-teszt nem jelzi előre megbízhatóan a PPH kialakulását, vérzés hiányában ezért nem indokolt rutinszerü elvégzése, de hasznos információval szolgálhat a standard haemostasis alvadási tesztekkel együtt a coagulopathiában vagy egyéb vérzékenységben szenvedő betegek esetében. A szülészeti vér- zés tekintetében rizikófaktorokkal rendelkező, de egészséges haemostasisrendszerrel bíró terheseknél a kiinduló VE POC-teszt - nem kötelező jelleggel, egyéni elbírálás alapján - szintén elvégezhető, de vérzés hiányában intervenciót nem tesz szükségessé.

PPH ellátása során a lehető legkorábban szükséges az antifibrinolyticus hatású TXA alkalmazása (l $\mathrm{g}$ iv.; amennyiben a vérzés 30 perc után is folytatódik, vagy 24 
órán belül újra jelentkezik, ismételni szükséges), mert a WOMAN-tanulmány eredményei alapján szignifikánsan csökkenti a vérzésből eredő halálozást [47].

A FIBTEM-A5 értéke pontosabban jelzi a PPH progresszióját, mint a Clauss szerinti fibrinogénszint-meghatározás. A PPH ellátása során legalább $8 \mathrm{E}$ allogén vérkészítményre szoruló, súlyos vérzésig progrediáló betegek FIBTEM-A5 medián értéke 12 mm-nek (fibrinogénszint 2,1 g/l), míg a nem progrediáló betegek FIBTEM-A5 medián értéke 19 mm-nek (fibrinogénszint 3,9 g/l) bizonyult. FIBTEM-A $5<12$ mm érték esetén ezért indokolt fibrinogénkoncentrátum adása a FIBTEM-A5 $\geq 16$ mm célérték eléréséig [43]. A fibrinogénszint $1 \mathrm{~g} / 1$-rel történő emeléséhez hozzávetőlegesen $60 \mathrm{mg} / \mathrm{kg}$, a FIBTEM-A5 2 mm-rel történő növeléséhez 12,5 mg/ $\mathrm{kg}$ fibrinogénkoncentrátum adása szükséges [43]. A fibrinogénszint érdemi emelésére friss fagyasztott plazma (FFP) önmagában alkalmatlan [48]. Ha a coagulopathia fennmarad normál-fibrinogénszint mellett, és az INR $>1,5$ vagy a VE POC-teszt faktorhiányt, coagulopathiát igazol, 4 faktoros (FII, FVII, FIX, FX) protrombinkomplex-koncentrátum adása előnyben részesítendó a gyors hatás, kisebb dilutio és volumenterhelés miatt (20-30 IU/ttkg) a FFP-val szemben. FFP 15-30 ml/ ttkg dózisban adható, de ez időigényes, és önmagában

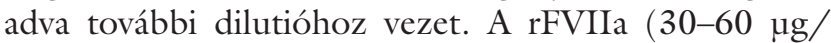
ttkg) csak végső esetben, hysterectomia megelőzésére, „mentő” terápiaként javasolt.

Amennyiben viszkoelasztikus tesztek nem érhetők el, támaszkodnunk kell a hagyományos laboratóriumi tesztek eredményeire, mert azok - a limitáló tényezők ellenére is - fontos információkkal segítik a kezelést. A PPH kezelési algoritmusát a $2 / a$ és $2 / b$ ábrán foglaltuk össze.

A szülészeti vérzések, különösen a PPH kezelésének fent részletezett speciális vonatkozásaitól eltekintve a kezelés további részleteit illetően utalunk a masszív vérzések ellátásával kapcsolatos nemzetközi és magyar ajánlásokra $[2,41-43]$.

A fent részletezett elvek mentén, de a helyi viszonyokhoz igazodó szülészeti PBM és szülészeti masszívvérzésellátási protokollok bevezetésével és alkalmazásával reményeink szerint Magyarországon tovább csökkenthető a felhasznált allogén vérkészítmények mennyisége, a masszív transzfúziók száma azok minden lehetséges szövődményével, az intenzív osztályos felvételek és a hysterectomiák aránya, illetve kedvező irányban befolyásolhatók az anyai morbiditási és mortalitási adatok [2, 16, 19, 43]. Széles körű alkalmazásuk tehát mindannyiunk elemi érdeke.

Anyagi támogatás: A közlemény megírása anyagi támogatásban nem részesült.

Szerzői munkamegosztás: O. Zs., D. T. és M. D. a kézirat és az ábrák elkészítésében, az irodalomgyújtésben és az egyes fejezetek elkészítésében egyaránt részt vettek.
A cikk végleges változatát valamennyi szerző elolvasta és jóváhagyta.

Érdekeltségek: A szerzők a kézirat elkészítésében pénzügyi vagy egyéb személyes érdekeltséggel nem rendelkeztek.

\section{Irodalom}

[1] Kumar N. Postpartum hemorrhage; a major killer of woman: review of current scenario. Obstet Gynecol Int J. 2016; 4: 116.

[2] Muñoz M, Stensballe J, Ducloy-Bouthors AS, et al. Patient blood management in obstetrics: prevention and treatment of postpartum haemorrhage. A NATA consensus statement. Blood Transfus. 2019; 17: 112-136.

[3] Say L, Chou D, Gemmill A, et al. Global causes of maternal death: a WHO systematic analysis. Lancet Glob Health 2014; 2 : e323-e333.

[4] Callaghan WM, Kuklina EV, Berg CJ. Trends in postpartum hemorrhage: United States, 1994-2006. Am J Obstet Gynecol. 2010; 202: 353.el-356.e6.

[5] Lier H, von Heymann C, Korte W, et al. Peripartum haemorrhage: haemostatic aspects of the new German PPH guideline. Transfus Med Hemother. 2018; 45: 127-135.

[6] Nagy S. Changing trends and indications for cesarean section in the last few decades. [A császármetszés javallatainak változása az elmúlt évtizedekben.] Orv Hetil. 2014; 155: 1140-1146. [Hungarian]

[7] Babik B. Haemostasis in pregnancy: a natural model of haemostasis resuscitation in patients with massive perioperative blood loss. [A véralvadási rendszer adaptációja terhességben: a hemosztázis-reszuszcitáció természetes modellje masszív vérzésben.] Aneszteziol Int Ter. 2017; 47(2): 9-23. [Hungarian]

[8] Hytten F. Blood volume changes in normal pregnancy. Clin Haematol. 1985; 14: 601-612.

[9] World Health Organization. Haemoglobin concentrations for the diagnosis of anaemia and assessment of severity. WHO/ $\mathrm{NMH} / \mathrm{NHD} / \mathrm{MNM} / 11.1$. Available from: http://www.who. int/vmnis/indicators/haemoglobin.pdf [accessed: March 14, 2020].

[10] Farkas Zs, Póka R. Changes in maternal hemoglobin and hematocrit values according to gestational age during pregnancy. [Várandósság alatti anyai hemoglobin és hematokrit értékek változásai egy nagy adatbázis alapján.] Magy Nőorv L. 2015; 78: 146-150. [Hungarian]

[11] Abbassi-Ghanavati M, Greer LG, Cunningham FG. Pregnancy and laboratory studies: a reference table for clinicians. Obstet Gynecol. 2009; 114: 1326-1331. [Correction: Obstet Gynecol. 2010; 115: 387.]

[12] Póka R, Damjanovich P, Károlyi PK, et al. Reference values of fibrinogen level in pregnancy. [A fibrinogénszint referenciaértékei várandósságban.] Magy Nőorv L. 2016; 79: 130-135. [Hungarian]

[13] Chi C, Kadir RA. Inherited bleeding disorders in pregnancy. Best Pract Res Clin Obstet Gynaecol. 2012; 26: 103-117.

[14] Alexander JM, Wortman AC. Intrapartum hemorrhage. Obstet Gynecol Clin N Am. 2013; 40: 15-26.

[15] Postpartum haemorrhage. Protocol of the Hungarian College of Obstetrics and Gynecology. 2008. [Postpartum vérzés. Szülészeti és Nőgyógyászati Szakmai Kollégium protokollja. 2008.] [Hungarian]

[16] Queensland Clinical Guidelines: Primary postpartum haemorrhage. Available from: https://www.health.qld.gov.au/_data/ assets/pdf_file/0015/140136/g-pph.pdf [accessed: March 14, 2020].

[17] Babik B, Fazakas J, Matusovits A, et al. Forced steps for making improvements in severe perioperative haemorrhage. [Lépés- 
kényszerben - új feladatok az életveszélyes perioperatív vérzések ellátásában.] Orv Hetil. 2019; 160: 203-213. [Hungarian]

[18] Surbek D, Vial Y, Girard T, et al. Patient blood management $(\mathrm{PBM})$ in pregnancy and childbirth: literature review and expert opinion. Arch Gynecol Obstetr. 2020; 301: 627-641.

[19] Patient Blood Management Guidelines: Module 5. Obstetrics and Maternity. Available from: https://www.blood.gov.au/system/files/documents/20180426-Module5-WEB.pdf [accessed: March 14, 2020].

[20] Neb H, Zacharowski K, Meybohm P. Strategies to reduce blood product utilization in obstetric practice. Curr Opin Anesthesiol. 2017; 30: 294-299.

[21] Pavord S, Daru J, Prasannan N, et al. UK guidelines on the management of iron deficiency in pregnancy. Br J Haematol. 2020; 188: 819-830.

[22] Recommendations to prevent and control iron deficiency in the United States. Available from: https://www.cdc.gov/mmwr/ preview/mmwrhtml/00051880.htm [accessed: March 14, 2020].

[23] WHO recommendations on antenatal care for a positive pregnancy experience. World Health Organization, 2016. Available from: https://apps.who.int/iris/bitstream/handle/10665/ 250796/9789241549912-eng.pdf?sequence $=1$ [accessed: March $14,2020]$.

[24] Muńoz M, Acheson AG, Auerbach M, et al. International consensus statement on the perioperative management of anaemia and iron deficiency. Anaesthesia 2017; 72: 233-247.

[25] Bochicchio GV, Napolitano L, Joshi M, et al. Outcome analysis of blood product transfusion in trauma patients: a prospective, risk-adjusted study. World J Surg. 2008; 32: 2185-2189.

[26] Ranucci M, Baryshnikova E, Castelvecchio S, et al. Major bleeding, transfusions, and anemia: the deadly triad of cardiac surgery. Ann Thorac Surg. 2013; 96: 478-485.

[27] Turan A, Yang D, Bonilla A, et al. Morbidity and mortality after massive transfusion in patients undergoing non-cardiac surgery. Can J Anaesth. 2013; 60: 761-770.

[28] Inaba K, Branco BC, Rhee P, et al. Impact of plasma transfusion in trauma patients who do not require massive transfusion. J Am Coll Surg. 2010; 210: 957-965.

[29] Baharoglu MI, Cordonnier C, Al-Shahi Salman R, et al. Platelet transfusion versus standard care after acute stroke due to spontaneous cerebral haemorrhage associated with antiplatelet therapy (PATCH): a randomised, open-label, phase 3 trial. Lancet 2016; 387: 2605-2613.

[30] Warner MA, Chandran A, Jenkins G, et al. Prophylactic plasma transfusion is not associated with decreased red blood cell requirements in critically ill patients. Anesth Analg. 2017; 124: 1636-1643.

[31] Warner MA, Jia Q, Clifford L, et al. Preoperative platelet transfusions and perioperative red blood cell requirements in patients with thrombocytopenia undergoing noncardiac surgery. Transfusion 2016; 56: 682-690.

[32] Bolton-Maggs PH, Cohen H. Serious Hazards of Transfusion (SHOT) haemovigilance and progress is improving transfusion safety. Br J Haematol. 2013; 163: 303-314.

[33] Muñoz M, Peña-Rosas JP, Robinson S, et al. Patient blood management in obstetrics: management of anaemia and haematinic deficiencies in pregnancy and in the post-partum period: NATA consensus statement. Transfus Med. 2018; 28: 22-39.

[34] Grotegut CA, Paglia MJ, Johnson LN, et al. Oxytocin exposure during labor among women with postpartum hemorrhage sec- ondary to uterine atony. Am J Obstet Gynecol. 2011; 204: 56.el-56.e6.

[35] Royal College of Obstetricians and Gynaecologists. Prevention and management of postpartum haemorrhage. Green-top guideline No. 52. BJOG 2017; 124: el06-el49.

[36] Smith C, Shippam W. Intraoperative cell salvage in obstetrics. In: Brown J, Abir G. (eds.) Obstetric anaesthesia. World Federation of Societies of Anesthesiologists, 2018. Available from: https:// www.wfsahq.org/components/com_virtual_library/media/6a0 Ofa55lf0ecea 40 b49cldfdf40a6e8-380-Cell-salavage-in-obstetrics.pdf [accessed: March 19, 2020].

[37] Goucher H, Wong C, Patel SK, et al. Cell salvage in obstetrics. Anesth Analg. 2015; 121: 465-468.

[38] Li XF, Fortney JA, Kotelchuck M, et al. The postpartum period: the key to maternal mortality. Int J Gynaecol Obstet. 1996; 54: $1-10$.

[39] Merrick C. (ed.) American College of Surgeons. Advanced Trauma Life Support ${ }^{\circledast}$. Student Course Manual. Tenth Edition. American College of Surgeons, Chicago, IL, 2018.

[40] Csorba R. Management of postpartum haemorrhage. [Szülést követő vérzések megelőzése és kezelése.] Orv Hetil. 2012; 153: 643-648. [Hungarian]

[41] Kozek-Langenecker SA, Ahmed AB, Afshari A, et al. Management of severe perioperative bleeding: guidelines from the European Society of Anaesthesiology: first update 2016. Eur J Anaesthesiol. 2017; 34: 332-395.

[42] Babik B, Blaskó Gy, Fazakas J, et al. Management of life-threatening perioperative haemorrhages. [Az életveszélyes perioperatív vérzések ellátása. A Magyar Aneszteziológiai és Intenzív Terápiás Társaság szakmai irányelve, 2013.] Aneszteziol Int Ter. 2013; 43: 113-143.] [Hungarian]

[43] Görlinger K, Pérez-Ferrer A, Dirkmann D, et al. The role of evidence-based algorithms for rotational thromboelastometryguided bleeding management. Korean J Anesthesiol. 2019; 72: 297-322

[44] de Lange NM, van Rheenen-Flach LE, Lancé MD, et al. Peripartum reference ranges for ROTEM $(\mathrm{R})$ thromboelastometry. Br J Anaesth. 2014; 112: 852-859.

[45] Oudghiri M, Keita H, Kouamou E, et al. Reference values for rotation thromboelastometry $\left(\right.$ ROTEM $\left.^{\circledast}\right)$ parameters following non-haemorrhagic deliveries. Correlations with standard haemostasis parameters. Thromb Haemost. 2011; 106: 176-178.

[46] Solomon C, Collis RE, Collins PW. Haemostatic monitoring during postpartum haemorrhage and implications for management. Br J Anaesth. 2012; 109: 851-863.

[47] WOMAN Trial Collaborators (Shakur H, Roberts I, Fawole B, et al.). Effect of early tranexamic acid administration on mortality, hysterectomy, and other morbidities in women with postpartum haemorrhage (WOMAN): an international, randomised, double-blind, placebo-controlled trial. Lancet 2017; 389: 21052116. [Correction: Lancet 2017; 389: 2104.]

[48] Innerhofer P, Fries D, Mittermayr M, et al. Reversal of traumainduced coagulopathy using first-line coagulation factor concentrates or fresh frozen plasma (RETIC): a single-centre, parallelgroup, open-label, randomised trial. Lancet Haematol. 2017; 4: e258-e271.

(Mühl Diána dr., Pécs, Ifjúság út 13., 7624 e-mail cím: drdianamuhl@gmail.com)

A cikk a Creative Commons Attribution 4.0 International License (https://creativecommons.org/licenses/by/4.0/) feltételei szerint publikált Open Access közlemény, melynek szellemében a cikk bármilyen médiumban szabadon felhasználható, megosztható és újraközölhetö, feltéve, hogy az eredeti szerző és a közlés helye, illetve a CC License linkje és az esetlegesen végrehajtott módosítások feltüntetésre kerülnek. (SID_1) 